\title{
Students Teaching Astronomy Related Science (STARS)
}

\author{
Reynee Kachur ${ }^{1}$, Sara Seidling ${ }^{1}$, and Lindsey DeVries ${ }^{2}$ \\ ${ }^{1}$ Science Outreach, University of Wisconsin, Oshkosh, WI \\ ${ }^{2}$ Lighted School House, Oshkosh Area School District, Oshkosh, WI
}

\begin{abstract}
The Students Teaching Astronomy Related Science (STARS) program was designed to promote the interest in space-related science to the Oshkosh Area School District Lighted School House (LSH) K- $5^{\text {th }}$ grade students. Through a partnership with UW Oshkosh Science Outreach and the LSH, the STARS program provided $60 \mathrm{~K}-5^{\text {th }}$ graders of the LSH program 12 weeks of hands-on learning experiences dealing with space and aerospace content outside of the regular school day and the normal science curriculum. The astronomy related science curriculum developed for this program utilized activities from UW Oshkosh Science Outreach and NASA, and included two visits to the Buckstaff Planetarium for an age appropriate planetarium show. Results of this project indicate that this program was successful in increasing the knowledge of space-related science, brought science to "life" for elementary students, and made space and aerospace education exciting and engaging.
\end{abstract}

\section{Introduction}

The University of Wisconsin Oshkosh (UW Oshkosh) is a state-assisted, non-profit institution of higher education. Its mission is to provide undergraduate, select graduate, and continuing/professional education opportunities. UW Oshkosh also engages in research and serves as a regional educational, cultural, and economic development resource. The Science Outreach program, housed at UW Oshkosh in the College of Letters and Science, is devoted to making science education accessible, exciting, and up-to-date for students, teachers, and the community. The Science Outreach department's goal is to expel science misconceptions and support the University's mission through interactive educational experiences at the elementary, middle, and high school levels.

The Oshkosh Area School Districts (OASD) Lighted School House Program (LSH) at Washington Elementary School in Oshkosh offers academic and enrichment opportunities to students before and after regular school hours. Washington Elementary is kept lit during an extended day to symbolize the great range of formal and informal learning activities available to students, even after the regular school day is finished. This program has been highly successful and provides services to over 60 students and many community members each semester.

The OASD LSH program is federally funded by the 21st Century Community Learning Center (CLC) Grant. The CLC grants, formulated under the No Child Left Behind Act, is a competitive grant process which provides funding to schools failing to meet academic benchmarks and or have high poverty rates. Washington Elementary School in Oshkosh was awarded this grant to provide academic and enrichment opportunities to its economically disadvantaged students and minorities so that they are equally exposed to a variety of programs that enhance educational and social experiences as compared to their middle and upper socioeconomic class peers. 
The LSH after-school program offers a nutritious snack at 2:45 p.m. followed by one hour of homework help. This is then followed by one hour of enrichment activities that have been guided by research to benefit children's' social, physical, character and academic development. These activities include physical fitness, nutrition, conflict resolution, social skills, leadership skills, career exploration, service-learning projects, team building, injury prevention, arts and crafts, foreign languages, science and nature. All activities occur in a safe, healthy, and positive environment.

The Students Teaching Astronomy Related Science (STARS) program is a fusion of the UW Oshkosh Science Outreach program with the LSH program. This blend of after school enrichment activities focused on space-related science targeted at $\mathrm{K}-5^{\text {th }}$ graders was designed to increase the knowledge of space-related science content, bring science to "life" for students, and to encourage students to pursue additional STEM curriculum or careers. By targeting the LSH $\mathrm{K}-5^{\text {th }}$ grade students with real-world applications of science, students can build confidence in science and math and develop positive attitudes towards science in general.

\section{Program Details}

A total of six UW Oshkosh college students employed by Science Outreach participated in this 12 week program of providing hands-on aerospace-related science instruction to approximately $60 \mathrm{LSH} \mathrm{K}-5^{\text {th }}$ graders (on average 10 students per grade level per week). In addition, three UW Oshkosh National Science Teacher Association members and one Environmental Health major volunteered their time at Washington Elementary School for this program.

A schedule of curriculum activities was developed by UW Oshkosh Science Outreach and the LSH program coordinators (Table 1). Based on the UW Oshkosh and LSH calendars, a total of 12 weeks were identified for UW Oshkosh Science Outreach to visit Washington Elementary for the STARS program. The program began on September 29, 2011 and ended on January 19, 2012. To maximize student to teacher ratio and the number of adults familiar with the activity, the $\mathrm{K}-5^{\text {th }}$ grade students were divided into two groups $-\mathrm{K}-2^{\text {nd }}$ graders and $3^{\text {rd }}-5^{\text {th }}$ graders. Two Science Outreach teaching assistants (TAs) were assigned to each group. Each week a different set of activities were planned for each age group to address the myriad of aerospace science themes. Table 1 outlines the activities plan and schedule for the STARS program. Each week, Science Outreach TAs would prepare for, gather supplies, learn the content, and travel from the university to Washington Elementary to teach the science concepts through a hands-on activity.

The curriculum was selected to cover a wide variety of astronomy related topics - from the solar system, comets, individual planets, exploration of space, and human survival in space. In addition, two planetarium shows (Monsters in the Sky and Earth and the Solar System) were revised and updated to provide additional content for the STARS participants.

\section{Results}

This program enabled both college students employed by Science Outreach and K-5 ${ }^{\text {th }}$ grade students at Washington Elementary to learn new aerospace curriculum. All results for this grant are qualitative - informal verbal surveys of college students by grant directors, and informal verbal surveys of the K-5 students by LSH coordinators and the grant director. 
For the UW Oshkosh Science Outreach college teaching assistants, this experience provided a weekly opportunity to "be" in a classroom in front of a group of students. Every teaching assistant who participated in this program developed classroom management skills, a thorough understanding of the science content, and broadened their understanding of science and teaching. By participating in this program, each teaching assistant gained confidence in their teaching skills and experience in teaching science to K-5 students.

For the K-5 $5^{\text {th }}$ graders in this program, the exposure to new curriculum and activities they would not normally get during their regular school year allowed these students to think outside of the box and provided an introduction to science in an informal environment. In addition:

This program got the $\mathrm{K}-5^{\text {th }}$ grade students excited about science and astronomy. Every week, the students would look forward to the aerospace activity and then ask what they were doing next week.

- LSH Coordinators

This enthusiasm was contagious - spreading from the students, to the Science Outreach teaching assistants, to both program coordinators. Pairing college students with elementary students also fostered a role model mentality, with the $\mathrm{K}-5^{\text {th }}$ grade students looking forward to when the "scientists" would be back.

Three of the Science Outreach teaching assistants in this program and all of the UW Oshkosh NSTA chapter volunteers were also women scientists. Having a positive female scientist role model for the LSH girls also helped encourage more elementary girls become excited about doing science. Although not one of our original goals, encouraging young girls to participate in and try more science became an offshoot of this grant, and will be included in future grant objectives and goals.

The hands-on activities covered a variety of student interests and learning styles, and allowed students to build more confidence in doing scientific activities. The STARS program engaged students in the LSH program in a space related curriculum in order to nurture the interest in STEM careers.

\section{Conclusion}

Through the STARS program, UW Oshkosh Science Outreach used the NASA curriculum for many of the STARS hands-on activities. Since the completion of the STARS program, Science Outreach has used many of these activities at other programs in the area, enhancing the sustainability of this program. In addition, the relationship between Science Outreach and the LSH program has been strengthened and will continue to provide science activities to encourage elementary students to have success in science in the future. 
Table 1: Schedule for the 2011-2012 STARS program.

\begin{tabular}{|c|c|c|c|}
\hline & Topic & White Dwarfs (K-2) & Red Giants (3-5) \\
\hline Sept. $29^{\text {th }}$ & The Moon & $\begin{array}{ll} & \text { Moon Cookies } \\
- & \text { How Can the Little } \\
\text { Moon Hide the Giant } \\
\text { Sun? }\end{array}$ & - Moon Cratering \\
\hline Oct. $6^{\text {th }}$ & Space Exploration & - Egg Drop & - $\quad$ Egg Drop \\
\hline Oct. $13^{\text {th }}$ & Space Exploration & $\begin{array}{ll}\text { - } & \text { Film Canister } \\
& \text { Rockets } \\
\text { - } & \text { Rocket Science with } \\
& \text { Balloons }\end{array}$ & $\begin{array}{l}\text { - Paper Rockets (Build } \\
\text { and Test Launch) } \\
\text { - Wind Tunnel }\end{array}$ \\
\hline Oct. $20^{\text {th }}$ & To the Sun & - How Big is the Sun? & $\begin{array}{ll}- & \text { Rocket Paper } \\
\text { Rockets (Modify and } \\
\text { Launch) }\end{array}$ \\
\hline Oct. $27^{\text {th }}$ & \multicolumn{3}{|c|}{ - $\quad$ No Lighted School House } \\
\hline Nov. $3^{\text {rd }}$ & Solar System & \multicolumn{2}{|c|}{ - Planetarium Show: Monsters in the Sky! } \\
\hline Nov. $10^{\text {th }}$ & Life on Mars & $\begin{array}{l}\text { - Edible Mars Rovers } \\
\text { - Can Things Live } \\
\text { Here? }\end{array}$ & $\begin{array}{l}\text { Do the Mystery } \\
\text { Samples Contain } \\
\text { Life? An exploration } \\
\text { offinding life in } \\
\text { space }\end{array}$ \\
\hline Nov. $17^{\text {th }}$ & \multicolumn{3}{|c|}{ - $\quad$ No Lighted School House } \\
\hline Nov. $24^{\text {th }}$ & \multicolumn{3}{|c|}{ - THANKSGIVING - No Lighted School House } \\
\hline Dec. $1^{\text {st }}$ & Constellations & $\begin{array}{l}\text { - Stories in the Stars } \\
\text { - Star Finders }\end{array}$ & $\begin{array}{l}\text { - } \quad \text { 3D Constellations } \\
\text { - } \quad \text { Star Finders }\end{array}$ \\
\hline Dec. $8^{\text {th }}$ & Solar System & \multicolumn{2}{|c|}{ - Planetarium Show: Earth and the Solar System } \\
\hline Dec. $15^{\text {th }}$ & \multicolumn{3}{|c|}{ - No Lighted School House } \\
\hline Dec. $22^{\text {nd }}$ & \multicolumn{3}{|c|}{ - No Lighted School House } \\
\hline $\operatorname{Jan} 3^{\text {rd }}$ & Solar System & $\begin{array}{ll}\text { - } & \text { Make Play Dough } \\
\text { - } & \text { A 3D Model of the } \\
\text { Earth and Moon }\end{array}$ & $\begin{array}{ll}\text { - } & \text { Make Play Dough } \\
\text { - } & \text { A 3D Model of the } \\
\text { Earth and Moon }\end{array}$ \\
\hline Jan. $5^{\text {th }}$ & Surviving in Space & $\begin{array}{l}\text { Food Preparation for } \\
\text { Space }\end{array}$ & $\begin{array}{ll}\text { - Food Preparation for } \\
\text { Space }\end{array}$ \\
\hline Jan. $17^{\text {th }}$ & Galaxies & - Galactic Mobile & - Galactic Mobile \\
\hline Jan. $19^{\text {th }}$ & Comets & $\begin{array}{ll}\text { - } & \text { Edible Comet } \\
\text { - } & \text { Comet on a Stick }\end{array}$ & $\begin{array}{ll}\text { - } & \text { Make a Comet } \\
\text { - } & \text { Edible Comet }\end{array}$ \\
\hline
\end{tabular}

